\title{
A new species of Thecadactylus from Sint Maarten, Lesser Antilles (Reptilia, Squamata, Gekkonidae)
}

\author{
Gunther Köhler ${ }^{1, \dagger}$, Milan Vesely ${ }^{2, \ddagger}$ \\ I Forschungsinstitut und Naturmuseum Senckenberg, Senckenberganlage 25, 60325 Frankfurt a.M., Ger- \\ many 2 Department of Zoology, Faculty of Natural Sciences, Palacky University, tr. Svobody 26, 77146 Olo- \\ mouc, Czech Republic \\ † urn:lsid:zoobank.org:author:26AFE6BA-9ABC-4EAE-93E8-CEFA92CCEC42 \\ † urn:lsid:zoobank.org:author:2A36A593-38D1-4687-A38D-A35794B174B0 \\ Corresponding author: Gunther Köbler (gkoehler@senckenberg.de)
}

Academic editor: Hans-Dieter Sues | Received 04 May 2011 | Accepted 24 June 2011 | Published 13 July 2011

urn:lsid:zoobank.org:pub:D2CB2B84-A73E-47C4-AB88-F2DA1D2095A2

Citation: Köhler G, Vesely M (2011) A new species of Thecadactylus from Sint Maarten, Lesser Antilles (Reptilia, Squamata, Gekkonidae). ZooKeys 118: 97-107. doi: 10.3897/zookeys.118.1476

\begin{abstract}
We describe a new species of Thecadactylus from the Caribbean island of Sint Maarten. The new species differs from all other species in the genus by having a distinct dorsal pattern of numerous irregular but sharply deliminated black spots and blotches on an otherwise almost patternless background.
\end{abstract}

\section{Keywords}

Gekkonidae; Lesser Antilles; new species; Reptilia; Sint Maarten; Squamata; Thecadactylus.

\section{Introduction}

Turnip-tailed geckos (genus Thecadactylus) are moderate-sized to large geckos distributed from southeastern Mexico across most of Central America and mesic tropical South America, and also occupy the Lesser Antilles (Russell and Bauer 2002). Whereas these geckos have traditionally been understood as a monotypic genus (e.g., Peters and Donoso-Barros 1970; Hoogmoed 1973; Avila-Pires 1995), currently two species of 
Thecadactylus are recognized (Bergmann and Russell 2007): T. rapicauda (Houttuyn, 1782) and T. solimoensis Bergmann \& Russell, 2007. All Thecadactylus populations from the Lesser Antilles have always been considered as conspecific with T. rapicauda (Powell et al. 1996, Censky and Kaiser 1999, Malhotra and Thorphe 1999).

In 2010, several specimens of a distinctly spotted Thecadactylus were collected on the island of Sint Maarten (also known as Saint Martin), Lesser Antilles, and imported to Germany by a pet trade dealer. In order to verify the geographic origin of these individuals, Stephan Prein and Maciej Oskroba visited Sint Maarten in April 2011. They indeed encountered Thecadactylus there and found that all specimens from this island had a distinctly spotted but otherwise patternless dorsum. A research of the pertinent literature revealed that this peculiar form had already been reported and illustrated from Sint Maarten (Breuil 2002, 2003). A comparison with the Thecadactylus from many localities across the wide geographic range of these geckos demonstrated that the Sint Maarten population represents an undescribed species and therefore, we describe it as a new species below.

\section{Materials and methods}

A list of the comparative specimens examined is provided in the Appendix. Abbreviations for museum collections follow those of Leviton et al. (1985). Furthermore, we have studied and analysed photographic material published in Powell (1996), Breuil (2002), Russell and Bauer (2002), and Powell et al. (2005). Nomenclature of scale characters follows that of Avila-Pires (1995). Subdigital lamellae were counted as suggested by Bergmann and Russell (2003). Scale sizes were measured using the ocular micrometer of a stereo microscope (Leica MZ 12) and rounded to the nearest $0.01 \mathrm{~mm}$. All other measurements were made using precision calipers and were rounded to the nearest $0.1 \mathrm{~mm}$. Head length was measured from the tip of the snout to the anterior margin of the ear opening. Snout length was measured from the tip of the snout to the anterior border of the orbit. Head width was determined as the distance between the oral ricti. Tail height and width were measured at the point reached by the heel of the extended hind leg. Dorsal and ventral scales were counted at midbody along the midline. Abbreviations used are DHL (number of medial dorsal scales in one head length), HL (head length), HW (head width), INL (infralabials), SAM (scales around midbody), SPL (supralabial scales), SVL (snoutvent length), and VHL (number of medial ventral scales in one head length). For the synonymy list, only those works have been included that cite actual specimens from Sint Maarten. Temperature was recorded at the type locality (see below) in the time from 11 - 16 April 2011 using an automatic temperature data logger (HOBO Pendant temp) placed on an upstanding tree trunk about $3 \mathrm{~m}$ above the ground in the shade recording at intervals of $2 \mathrm{~min}$. 


\section{Results}

\section{Thecadactylus oskrobapreinorum sp. $\mathrm{n}$.} urn:lsid:zoobank.org:act:0F9770AC-C296-462A-B23F-F3356ECC4BE5 http://species-id.net/wiki/Thecadactylus_oskrobapreinorum Figs $1-3$

Thecadactylus rapicauda: Breuil (2002, 2003; in part.), Bergmann and Russell (2007; in part.).

Holotype. SMF 92120, an adult male from Sint Maarten, near the southern edge of the village of Dawn Beach, $18.042^{\circ} \mathrm{N}, 63.023^{\circ} \mathrm{W}, 45 \mathrm{~m}$ elevation; collected 12 April 2011 by Stephan Prein and Maciej Oskroba.

Paratypes. SMF 92194, 92721-29, same collecting data as holotype.

Diagnosis. A species (SVL in largest specimen examined $99 \mathrm{~mm}$ ) of the genus Thecadactylus (sensu Russell and Bauer 2002) that differs from all other species in the genus by having a distinct dorsal pattern of numerous irregular but sharply deliminated black spots and blotches on an otherwise almost patternless background. Thecadactylus oskrobapreinorum lacks a dorsally directed postocular stripe (such stripe present in most specimens of T. solimoensis; see Bergmann and Russell 2007). Thecadactylus oskrobapreinorum differs further from T. rapicauda in the mean values of several morphometric and pholidotic characteristics, most pronounced in the number of subdigital lamellae and supralabial scales (see Table 1).

Description of the holotype. Adult male as indicated by partially everted hemipenes; SVL $95.5 \mathrm{~mm}$; tail length $75.0 \mathrm{~mm}$, tail complete; tail almost round in cross section, tail height $6.9 \mathrm{~mm}$, width $7.6 \mathrm{~mm}$; axilla to groin distance $37.0 \mathrm{~mm}$; head length $24.5 \mathrm{~mm}$; snout length $12.2 \mathrm{~mm}$; head width $20.5 \mathrm{~mm}$; shank length $16.2 \mathrm{~mm}$. Rostral large, rectangular, about twice as wide as deep, visible from above, and with a long median cleft extending from posterior margin; 2 relatively large, rectangular postrostrals; nostril bordered by rostral, first supralabial, 3 small postnasals and one postrostral; scales on snout and on loreal region granular, mostly keeled; 22 loreal scales in a longitudinal line between rostral and orbit; scales on upper and posterior portions of head slightly smaller than on snout; scales in supraorbital region not differentiated from those on upper part of head; supraciliary flap bordered by a double row of scales, 18 in outer row between anterior border of flap and a point above center of eye, with 7 small spines posteriorly; pupil four-lobed, vertically elongate; 8 supralabials to level below center of eye, total number 10, anterior supralabials subequal in size, below eyes decreasing in size; ear opening obliquely oval, $3.0 \times 1.5$ $\mathrm{mm}$ (length $\mathrm{x}$ height) distinctly smaller than eye (eye length $6.1 \mathrm{~mm}$ ); mental larger than adjacent scales, pentagonal; 2 relatively large postmentals, at each side followed by a row of smooth, polygonal scales, decreasing in size posteriorly, and in contact 
Table I. Selected measurements, proportions and scale characters of Thecadactylus oskrobapreinorum and T. rapicauda. Range is followed by mean value and standard deviation in parentheses. For abbreviations see text. For tail length, only complete original tails were measured.

\begin{tabular}{|c|c|c|c|}
\hline & & $\begin{array}{l}\text { T. oskrobapreinorum } \\
\text { o } 4 \\
\text { o } 4 \\
\end{array}$ & $\begin{array}{l}\text { T. rapicauda } \\
\text { ㅇ } 11 \\
+9\end{array}$ \\
\hline \multirow[t]{2}{*}{ SVL } & $\hat{0}$ & $86.0-96.5(90.6 \pm 3.83)$ & $74.0-95.0(85.5 \pm 6.87)$ \\
\hline & q & $87.0-99.0(94.0 \pm 4.85)$ & $79.0-119.0(93.9 \pm 11.65)$ \\
\hline \multirow[t]{2}{*}{ Tail length } & $\hat{0}$ & $75.0-76.0(75.3 \pm 0.47)$ & $65.0-72.0(68.5 \pm 3.50)$ \\
\hline & q & $71.0-83.0(77.0 \pm 6.00)$ & $75.0-76.0(75.3 \pm 0.47)$ \\
\hline \multirow[t]{2}{*}{ HL } & $\hat{0}$ & $22.6-24.5(23.5 \pm 0.67)$ & $18.2-24.7(21.5 \pm 1.75)$ \\
\hline & q & $23.0-25.0(24.3 \pm 0.79)$ & $18.8-28.0(23.2 \pm 2.56)$ \\
\hline \multirow[t]{2}{*}{ HW } & $\hat{0}$ & $17.3-20.5(18.4 \pm 1.25)$ & $14.7-19.9(17.3 \pm 1.95)$ \\
\hline & q & $17.6-19.1(18.2 \pm 0.58)$ & $13.2-22.9(17.9 \pm 2.74)$ \\
\hline \multirow[t]{2}{*}{ Shank length } & $\hat{0}$ & $13.2-16.2(14.2 \pm 1.21)$ & $10.0-14.5(12.7 \pm 1.29)$ \\
\hline & q & $14.0-15.9(14.5 \pm 0.81)$ & $10.6-17.2(14.3 \pm 1.95)$ \\
\hline \multirow[t]{2}{*}{ Axilla-groin distance } & $0^{1}$ & $37.0-38.7(37.6 \pm 0.68)$ & $33.0-45.7(39.1 \pm 4.54)$ \\
\hline & q & $32.5-43.0(39.2 \pm 4.14)$ & $37.7-49.5(42.5 \pm 3.83)$ \\
\hline \multirow[t]{2}{*}{ Tail length / SVL } & $\hat{0}$ & $0.78-0.87(0.83 \pm 0.04)$ & $0.82-0.87(0.85 \pm 0.02)$ \\
\hline & q & $0.72-0.90(0.81 \pm 0.09)$ & $0.78-0.87(0.83 \pm 0.04)$ \\
\hline \multirow[t]{2}{*}{ HL / SVL } & $\hat{0}$ & $0.25-0.27(0.26 \pm 0.01)$ & $0.24-0.26(0.25 \pm 0.01)$ \\
\hline & q & $0.25-0.27(0.26 \pm 0.01)$ & $0.24-0.27(0.25 \pm 0.01)$ \\
\hline \multirow[t]{2}{*}{ Shank length / SVL } & $\hat{0}$ & $0.15-0.17(0.16 \pm 0.01)$ & $0.13-0.17(0.15 \pm 0.01)$ \\
\hline & q & $0.14-0.16(0.15 \pm 0.01)$ & $0.13-0.17(0.15 \pm 0.01)$ \\
\hline \multirow[t]{2}{*}{ Axilla-groin distance / SVL } & $\hat{0}$ & $0.38-0.43(0.42 \pm 0.02)$ & $0.41-0.53(0.46 \pm 0.03)$ \\
\hline & q & $0.37-0.43(0.42 \pm 0.02)$ & $0.42-0.49(0.46 \pm 0.02)$ \\
\hline \multicolumn{2}{|l|}{ Subdigital lamellae of 4 th toe } & $16-20(18.13 \pm 1.17)$ & $18-23(20.17 \pm 1.62)$ \\
\hline \multicolumn{2}{|c|}{ Subdigital lamellae of 4 th finger } & $16-19(17.88 \pm 1.05)$ & $17-23(19.67 \pm 2.13)$ \\
\hline \multicolumn{2}{|l|}{$\begin{array}{l}\text { Number of SPL to level below } \\
\text { center of eye }\end{array}$} & $6-8(6.63 \pm 0.70)$ & $8-10(8.62 \pm 0.62)$ \\
\hline \multicolumn{2}{|l|}{$\begin{array}{l}\text { Number of INL to level below } \\
\text { center of eye }\end{array}$} & $8-10(8.63 \pm 0.70)$ & $7-8(7.62 \pm 0.49)$ \\
\hline \multicolumn{2}{|l|}{ Number of postrostrals } & 2 & 2 \\
\hline \multicolumn{2}{|l|}{ Number of postmentals } & 2 & 2 \\
\hline \multicolumn{2}{|c|}{$\begin{array}{l}\text { Number of medial dorsal scales in } \\
\text { one head length }\end{array}$} & $72-92(81.25 \pm 7.60)$ & $64-88(75.15 \pm 8.24)$ \\
\hline \multicolumn{2}{|c|}{$\begin{array}{l}\text { Number of medial ventral scales } \\
\text { in one head length }\end{array}$} & $44-56(49.00 \pm 4.24)$ & $34-52(40.62 \pm 4.68)$ \\
\hline
\end{tabular}

with anterior infralabials; scales on chin granular, mostly pointed; scales on throat small, round, convex, juxtaposed; 8 (right) -7 (left) infralabials to level below center of eye, total number 10; infralabials mostly large, smooth, quadrangular to pentagonal, posterior ones smaller; dorsum of body with convex, juxtaposed to subimbricate scales with rounded posterior margins, about twice as large as scales on snout, largest dorsal scales about $0.35 \times 0.29 \mathrm{~mm}$ (length $\mathrm{x}$ width); about 72 median dorsal scales in 
one head length; ventral scales at midbody smooth, juxtaposed to subimbricate with rounded posterior margins, forming oblique rows, about $0.42 \times 0.39 \mathrm{~mm}$ (length $\mathrm{x}$ width); about 45 ventral scales in one head length; a gradual transition between dorsal and ventral scales; 218 scales around midbody; caudal scales smooth, imbricate, with rounded posterior margins, slightly larger ventrally; scales on limbs mostly smooth, subimbricate, with rounded posterior margins, equal to, to larger than dorsals; scales on posterior surfaces of forelimbs and on posterior and upper surfaces of hind limbs small, granular; fingers and toes depressed with a middorsal elevation, connected by a basal web; subdigital lamellae forming two transversely enlarged rows, divided by a median sulcus, 20 under fourth toe, 19 under fourth finger; claw on distal extremity of distal sulcus.

Coloration after one month in preservative (70\% ethanol) was recorded as follows: Dorsal surfaces of head, body, limbs, and tail grayish brown with numerous irregular but sharply deliminated, black spots and blotches; ventral surfaces of head, body, and

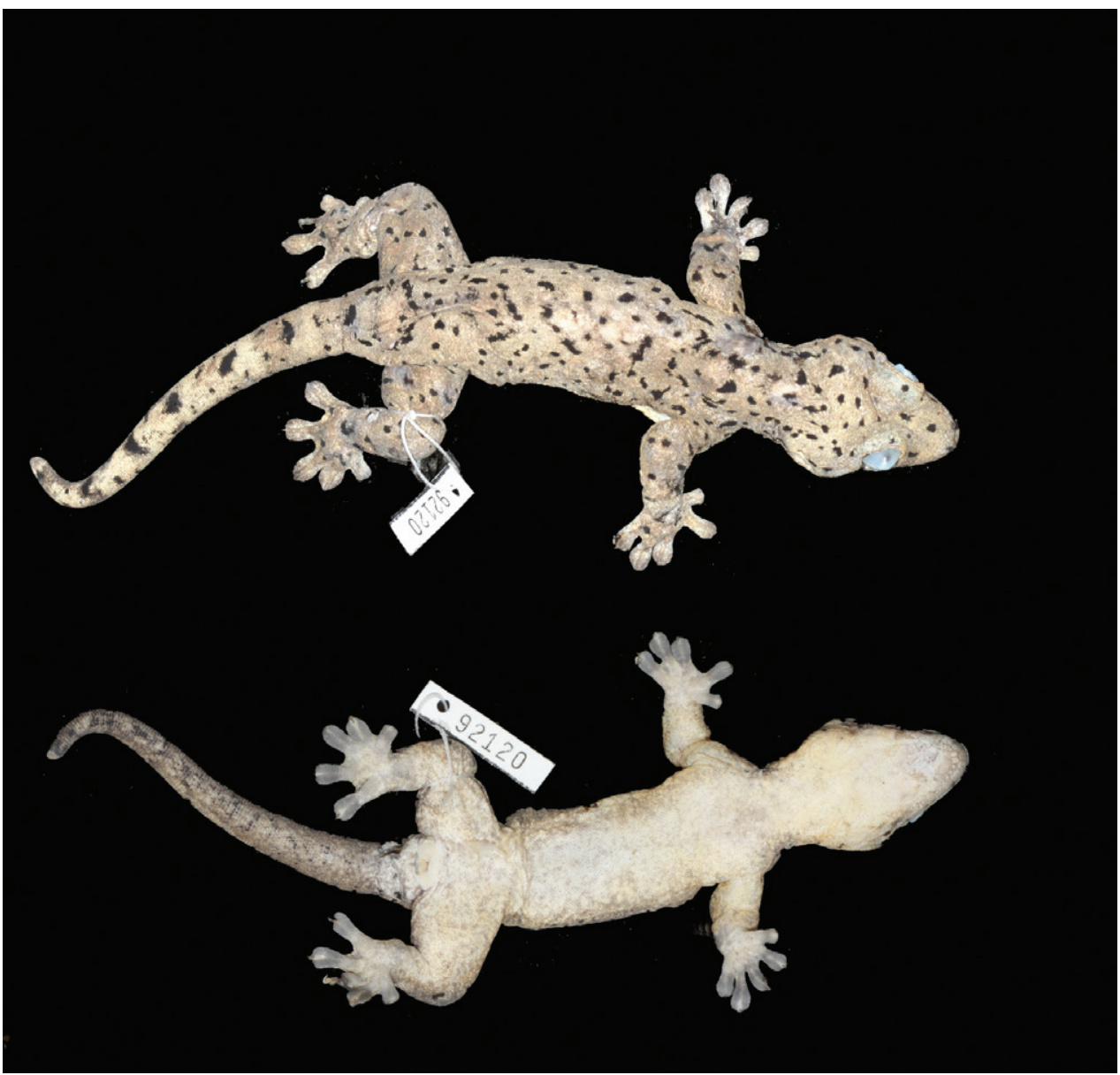

Figure I. Holotype of Thecadactylus oskrobapreinorum (SMF 92 I 20). SVL = $95.5 \mathrm{~mm}$. 

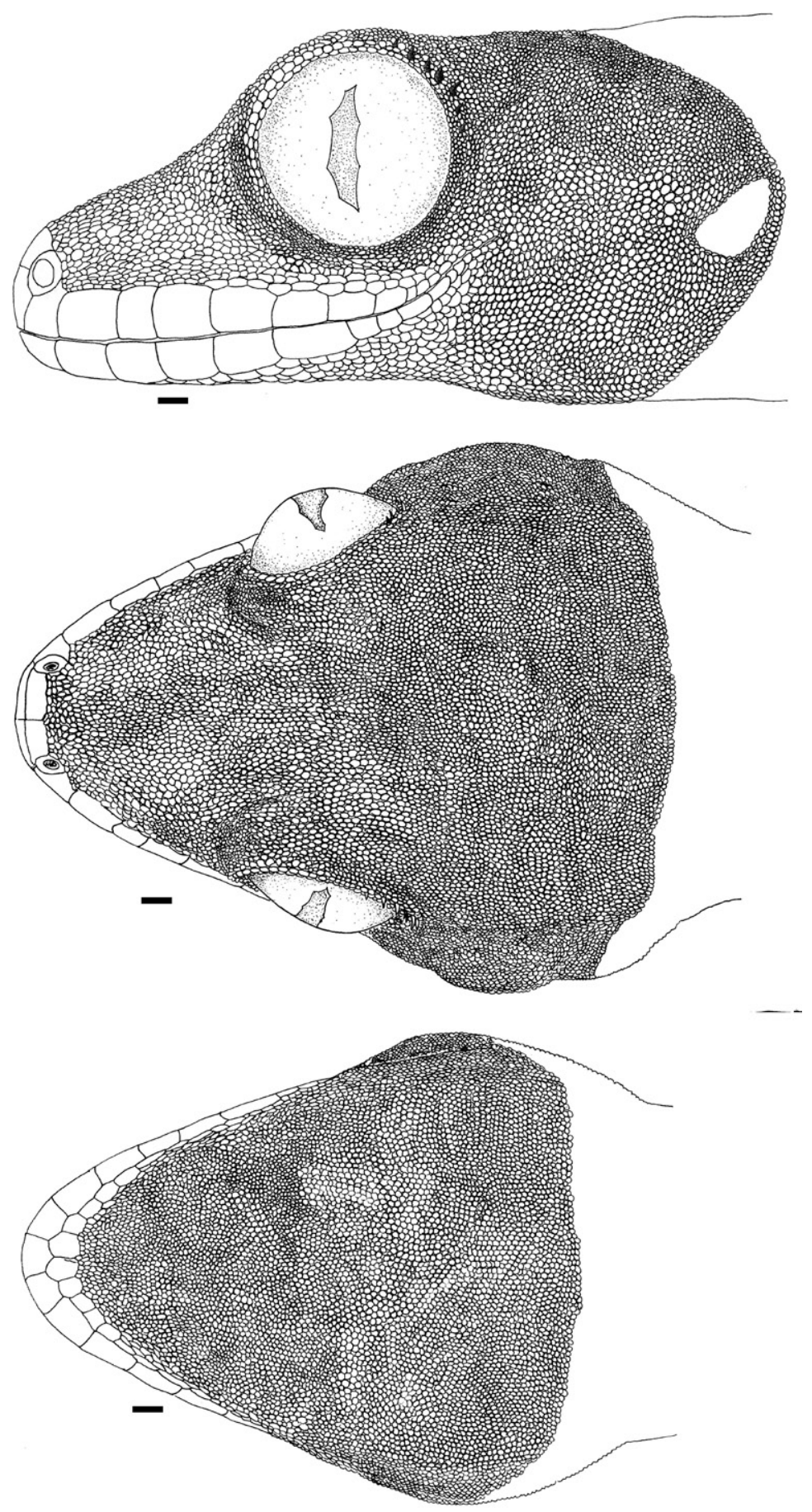

Figure 2. Head of holotype of Thecadactylus oskrobapreinorum (SMF 92 I 20). Scale bar equals $1.0 \mathrm{~mm}$. 

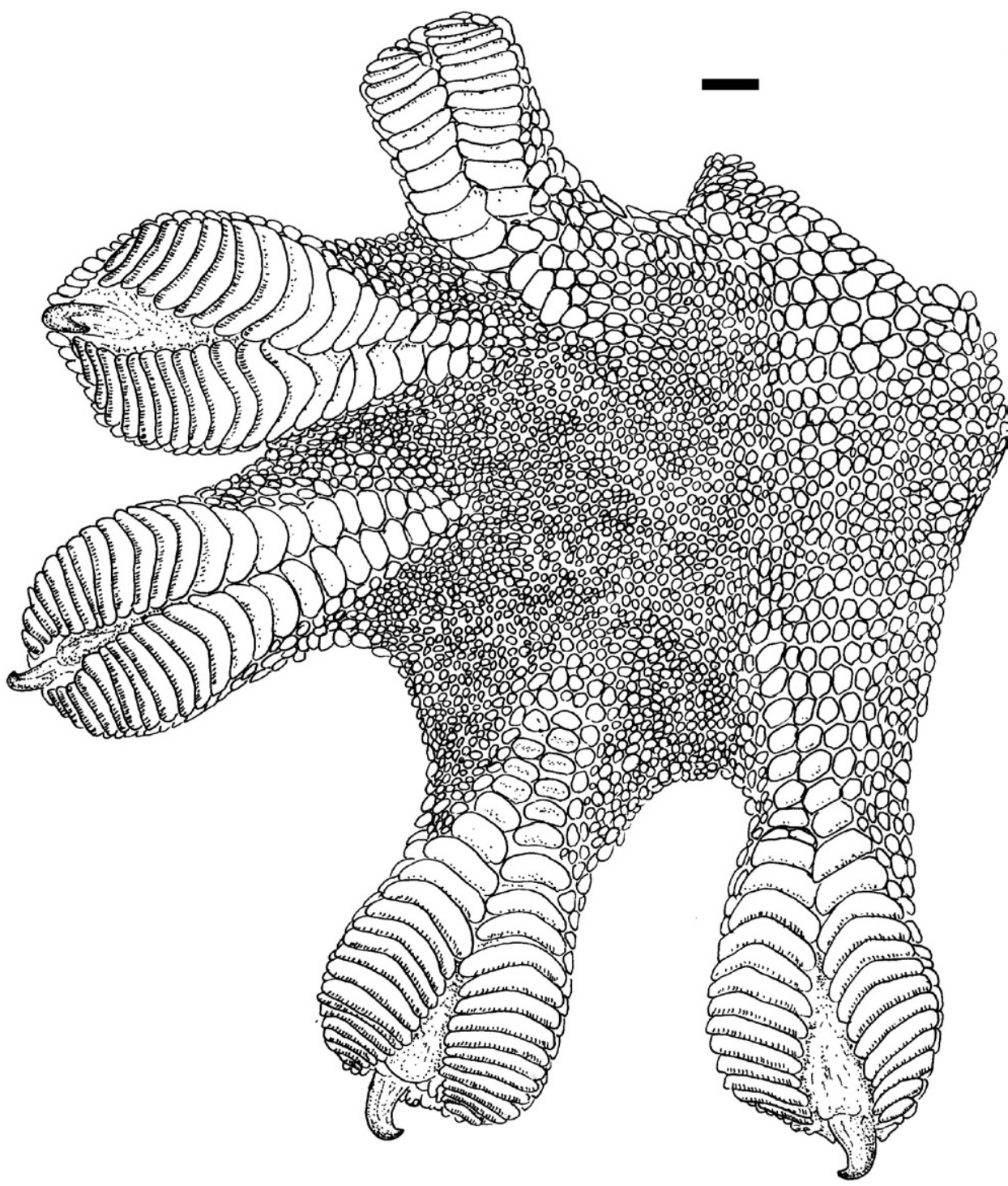

Figure 3. Right hind foot of holotype of Thecadactylus oskrobapreinorum (SMF 92120). Scale bar equals $1.0 \mathrm{~mm}$.

limbs cream with gray shading and faint gray reticulations; widened lamellae of fingers and toes gray; ventral surface of tail brown with dark grayish brown reticulations.

Variation. The paratypes agree well with the holotype in general appearance, morphometrics and scalation (see Table 1). Variation of coloration in life is illustrated in Fig. 4. As can be seen, the number and distribution of the dark spots and blotches varies between individuals as does the background color which ranges from pale pearl gray over pale grayish yellow to grayish olive. Scale size differences in certain areas of gular 


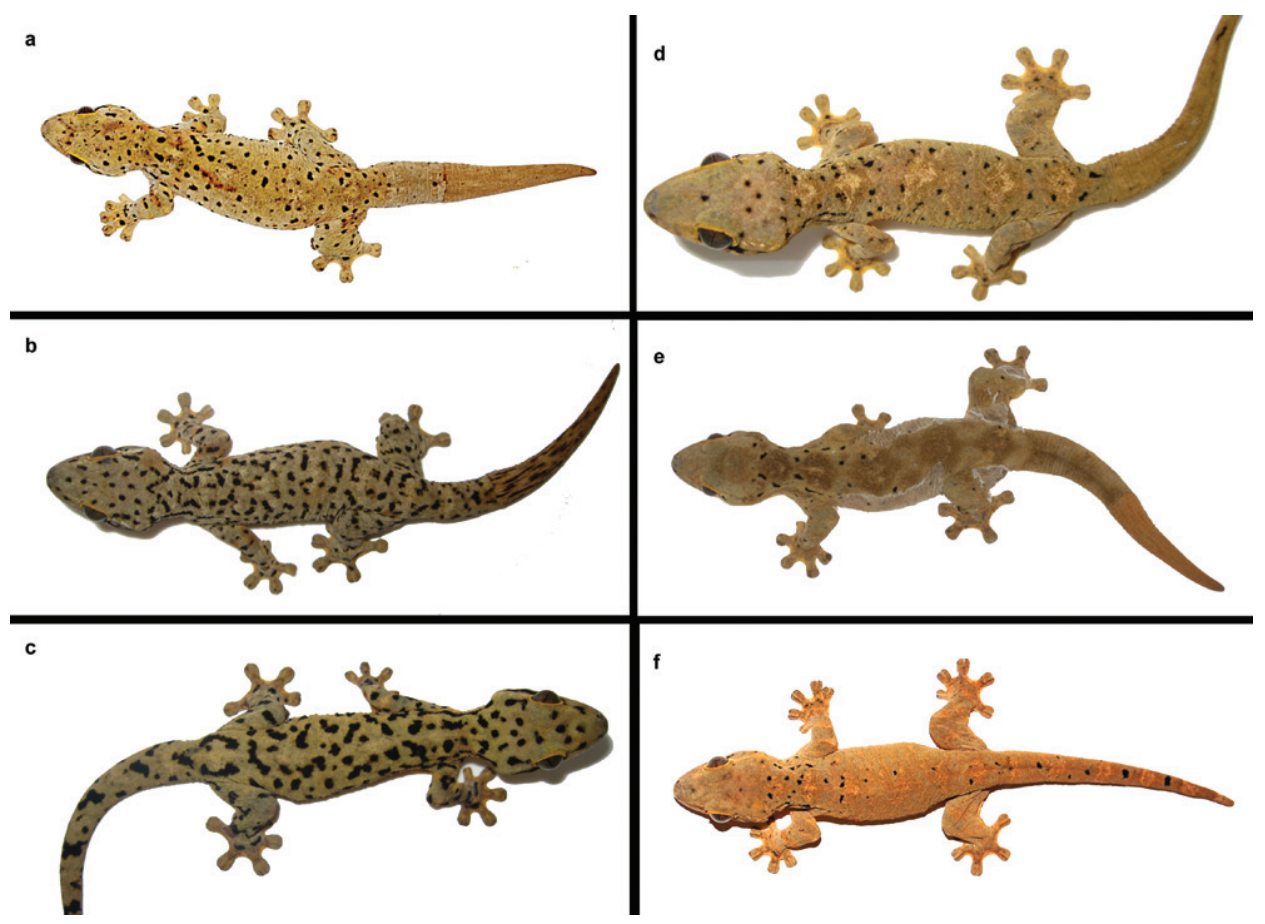

Figure 4. Thecadactylus oskrobapreinorum in life (specimens not preserved; all from Sint Maarten, Lesser Antilles). Photos a,e by Gunther Köhler; b,c,d by Stephan Prein, f by Maciej Oskroba

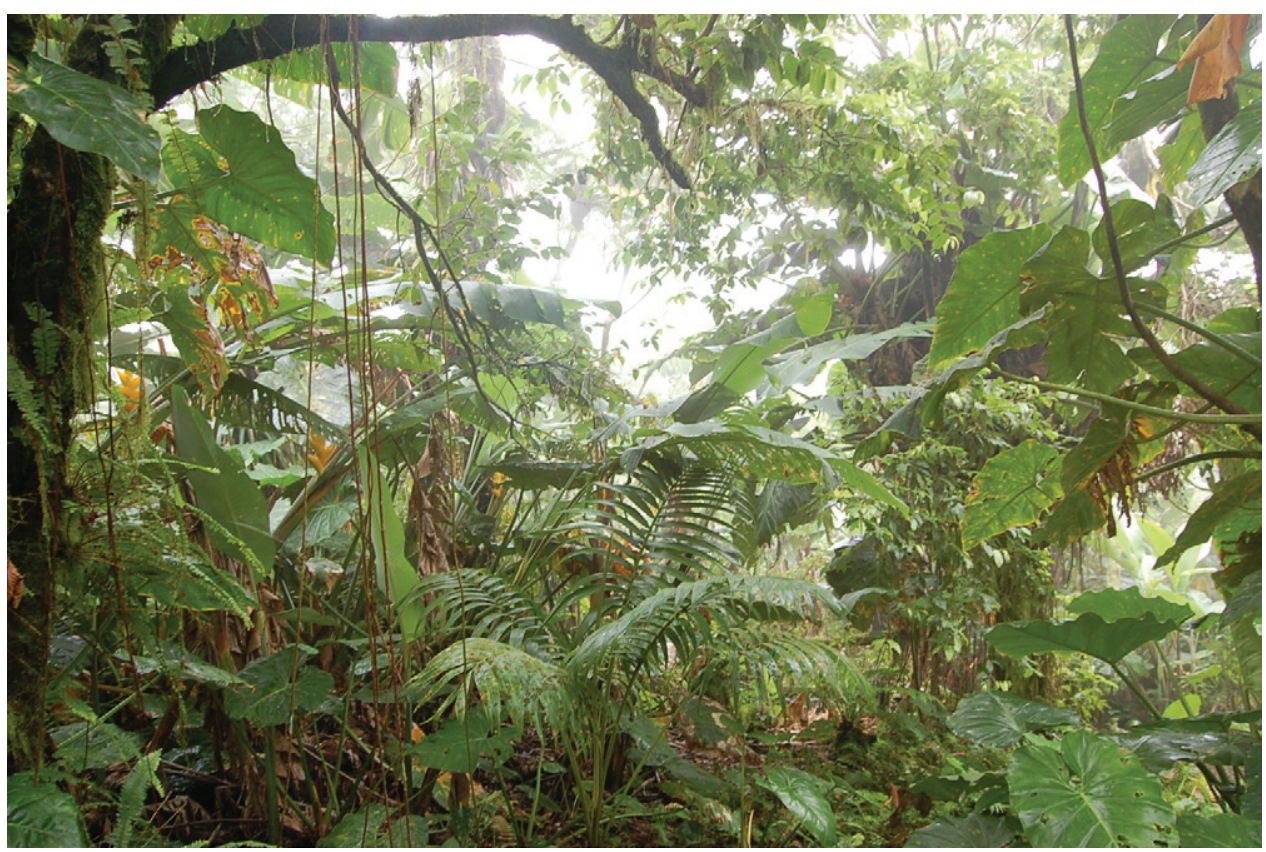

Figure 5. Habitat at the type locality of Thecadactylus oskrobapreinorum on Sint Maarten, Lesser Antilles. Photo by Maciej Oskroba 
and temporal region of male holotype are probably the result of bites from other males in territorial fights. The damaged parts of the skin are covered by smaller granular scales as it is typical for scar tissue.

Etymology. The name oskrobapreinorum is a construction in the genitive plural honoring Maciej Oskroba and Stephan Prein, two German herpetoculturists who directed our attention to this new species and made field observations on this gecko on the island of Sint Maarten.

Natural history notes. All type specimens were collected at night while the lizards were active on the lower parts of the trunks of large living trees within or at the edge of forested areas (see also Fig. 5). From 11-16 April 2011, the air temperature (measured in the shade) varied at the type locality from $21.1-23.7^{\circ} \mathrm{C}$ (mean $22.7^{\circ} \mathrm{C}$ ) in the morning hours and $24.6-28.2^{\circ} \mathrm{C}$ (mean $26.6^{\circ} \mathrm{C}$ ) in the afternoon.

Geographic Distribution. As currently known, Thecadactylus oskrobapreinorum is restricted to the island of Sint Maarten, Lesser Antilles. Although the type locality is in the Dutch portion of the island, the species is also known from several localities in the French portion (see records in Breuil 2002).

\section{Discussion}

The distinctive dorsal pattern in Thecadactylus oskrobapreinorum appears to be a fixed character in this species since no individuals without dark spots on a otherwise patternless dorsum have been documented (see also a photo of a specimen of this species in Breuil 2002, 2003). As described and illustrated, individuals of the Thecadactylus populations from the nearby islands of St. Eustatius, St. Barthelemy, and Saba show the "normal" dorsal pattern of T. rapicauda (Breuil 2002, Powell et al. 2005). However, Breuil (2002) pictures a specimen from the island of La Désiderade which exhibits a strikingly aberrant coloration with a almost white head contrasting with the mostly dark grayish body, limbs, and tail. A more comprehensive survey and analysis of variation, both of molecular genetic and of morphological traits, is needed in order to shed light on the actual species diversity of Thecadactylus on the Lesser Antilles.

We have not examined the types of the nominal species placed in the synonymy of Thecadactylus rapicauda (following e.g., Peters and Donoso-Barros 1970, Russell and Bauer 2002). However, based on the respective type localities, even given the vague nature of most of them, none of them came from near Sint Maarten, not even from the Lesser Antilles: Gekko laevis Daudin, 1802 (type locality: "Amérique méridionale"); Gekko surinamensis Daudin, 1802 (type locality: "Surinam"); and Pachydactylus tristis Hallowell, 1854 (type locality: "Liberia, west coast of Africa", in error fide Russell and Bauer 2002). Therefore, none of the aforementioned names can be applied to the species described herein. In the cases of Gekko laevis and Pachydactylus tristis, the types of both of which are lost and no accurate type locality given, the synonymy assignment to either T. rapicauda or T. solimoensis remains un- 
settled. Also, as pointed out by Bergmann and Russell (2007), additional molecular genetic work with more intensive sampling is needed in order to clarify the geographic boundaries between $T$. rapicauda and T. solimoensis.

\section{Acknowledgments}

Exportation permits were provided by Mervyn Butcher, Government of St. Maarten, Sint Maarten. For the loan of and/or access to specimens we thank William E. Duellman and John E. Simmons, University of Kansas, Natural History Museum (KU), Lawrence. Sebastian Lotzkat, Frankfurt, provided unpublished morphological data pertaining to Panamanian Thecadactylus. We thank Aaron M. Bauer, Villanova, for comments on an early draft of the manuscript.

\section{References}

Avila-Pires TCS (1995) Lizards of Brazilian Amazonia (Reptilia: Squamata). Zoologische Verhandelingen Leiden 299: 1-706.

Bergmann PJ, Russell AP (2003) Lamella and scansor numbers in Thecadactylus rapicauda (Gekkonidae): Patterns revealed through correlational analysis and implications for systematic and functional studies. Amphibia-Reptilia 24: 379-385. doi:10.1163/156853803322440826

Bergmann PJ, Russell AP (2007) Systematics and biogeography of the widespread Neotropical gekkonid genus Thecadactylus (Squamata), with the description of a new cryptic species. Zoological Journal of the Linnean Society 149: 339-370.

Breuil M (2002) Histoire Naturelle des Amphibiens et Reptiles Terrestres de l'Archipel Guadeloupéen. Guadeloupe, Saint-Martin, Saint-Barthélemy. Patrimoines Naturels 54: 1-339.

Breuil M (2003) A la découverte des Amphibiens \& Reptiles des Antilles. PLB Éditions, Gosier, Guadeloupe, 64 pp.

Censky EJ, Kaiser H (1999) The Lesser Antillean fauna. In: Crother, BI (Ed) Caribbean Amphians and Reptiles. Academic Press, San Diego, 181-221.

Daudin F (1802) Histoire naturelle générale et particulière des reptiles, Vol. 4. F. Dufart, Paris.

Duméril AMC, Bibron G (1836) Erpetologie générale ou histoire naturelle complete des reptiles. Vol. 3. Libr. Encyclopédique Roret, Paris, 528 pp.

Hallowell E (1854) Remarks on the geographical distribution of reptiles, with descriptions of several species supposed to be new, and corrections of former papers. Proceedings of the Academy of Natural Sciences of Philadelphia 1854: 98-105.

Hoogmoed MS (1973) Notes on the herpetofauna of Surinam IV. The Lizards and amphisbaenians of Surinam. Biogeographica 4: 1-419.

Houttuyn M (1782) Het onderscheid der salamanderen van de haagdissen in 't algemeen, en van de gekkos in 't byzonder aangetoond. Venhandelingen Uitgegeven door het Zeeuwsch Genootschap der Wetenschappen te Vlissingen, ser. 1, 9: 305-336. 
Kronauer DJC, Bergmann PJ, Mercer JM, Russell AP (2005) A phylogeographically distinct and deep divergence in the widespread Neotropical turnip-tailed gecko, Thecadactylus rapicauda. Molecular Phylogenetics and Evolution 34: 431-437. doi:10.1016/j. ympev.2004.10.009

Leviton AE, Gibbs RH, Heal E \& Dawson CC (1985) Standards in herpetology and ichthyology: part I. Standard symbolic codes for institutional resource collections in herpetology and ichthyology. Copeia 1985: 802-832.

Malhotra A, Thorpe, RS (1999) Reptiles \& Amphibians of the Eastern Caribbean. Macmillan Education Ltd., 88-92.

Powell R, Henderson RW, Adler K, Dundee HA (1996) An annotated checklist of West Indian amphibians and reptiles. In: Powell R, Henderson RW (Eds) Contributions to West Indian Herpetology. A Tribute to Albert Schwartz. Society for the Study of Amphibians and Reptiles, St. Louis, 51-93.

Powell R, Henderson RW, Parmelee JS (2005) The reptiles and amphibians of the Dutch Caribbean St. Eustatius, Saba, and St. Maarten. STENAPA, St. Eustatius, 191 pp.

Russell AP, Bauer AM (2002) Thecadactylus, T. rapicauda. Catalogue of American Amphibians and Reptiles 753: 1-16.

\section{Appendix}

\section{Comparative material examined}

Thecadactylus rapicauda - Brazil: Maranhão: SMF 8378. Colombia: Melgar, Tolima: SMF 70233. Guatemala: Sitio Arqueologico Quirigua, 76 m: SMF 84018. Honduras: Isla de Utila, near Iguana Station: SMF 79871; Isla de Utila, $1 \mathrm{~km}$ S Rock Harbour: SMF 77098; west end of Isla de Utila: SMF 77099; Río Platano Biosphere Reserve, vicinity of Río Cuyamel, $15^{\circ} 34.43^{\prime} \mathrm{N}, 8^{\circ} 0.248^{\prime} \mathrm{W}, 170 \mathrm{~m}$ : SMF 85940-41; Parque Nacional Patuca, Matamoros, $150 \mathrm{~m}$ : SMF 80824-25. Nicaragua: Bartola at Río San Juan, $10^{\circ} 58.37^{\prime} \mathrm{N}, 84^{\circ} 20.35^{\prime} \mathrm{W}, 30$ m: SMF 82103; Parque Nacional Saslaya, $13^{\circ} 42.84^{\prime} \mathrm{N}, 4^{\circ} 58.66^{\prime} \mathrm{W}, 400$ m: SMF 82875-77; Biosphere Reserve Bosawas, near Wiso, $13^{\circ} 59.67^{\prime} \mathrm{N}, 85^{\circ} 19.70^{\prime} \mathrm{W}, 246$ m: SMF 78555; El Recreo, S side Río Mico, 25 m: KU 113016. Panama: Volante: SMF 89601; Cerro Tebata, Bocas del Toro Province: SMF 83638. Surinam: no further data: SMF 8374. Trinidad: Hotel Robinson Crusoe, Scarborough: SMF 65848; Alefounder, Grafton Estate: SMF 65849, 66185, 66204; Prospect Estate: SMF 66829. Trinidad: no further data: SMF 8376. Venezuela: Puerto Caballo: SMF 8375; between Guaramaco and San Fernando: SMF 8377.

Thecadactylus solimoensis - Ecuador: Pastaza Province, Arutam Field Station, 700 $\mathrm{m}$ east from the Camp (coordinates of the Camp): $1^{\circ} 47.28^{\prime} \mathrm{S} 77^{\circ} 48.31^{\prime} \mathrm{W}, 790 \mathrm{~m}$ : SMF 91034. 